\title{
Transparent Dye-sensitized Module for Solar Windows
}

\author{
Lia Muliani, Jojo Hidayat, Shobih, Natalita Maulani Nursam, Erlyta Septa Rosa, \\ Putri Nur Anggraini, Lilis Retnaningsih. \\ Research Center for Electronic and Telecommunication, Indonesian Institute of Sciences (LIPI), \\ Bandung, 40135, Indonesia \\ *E-mail: liamuliani@gmail.com
}

doi: $10.20964 / 2021.03 .61$

Received: 25 November 2020 / Accepted: 14 January 2021 / Published: 31 January 2021

Dye-sensitized solar cells (DSCs) rely on a photoelectrochemical mechanism. Currently, one of the most significant developments of DSCs is intended toward developing a module for building-integrated photovoltaics (BIPVs). The DSC module could be achieved in a variety of colors and shapes and can perform under relatively low light intensity, making it suitable for solar windows as BIPVs. DSC modules for solar windows must have high transparency in addition to high electrical performance. The transparency of the module can be determined by the materials used and the fabrication process. In this work, we demonstrate the fabrication of a DSC module on transparent conductive glass substrates using a screen-printing method. The module consists of 16 sub-modules that were externally integrated. Each sub-module contained seven grid-type cells that were internally integrated via Z-type series connections. The total active area of the DSC module was $1,120 \mathrm{~cm}^{2}$. The current-voltage $(I-V)$ performance of the module was measured using a Keithley 2400 under direct sunlight. The measurement conducted under low light with an irradiation intensity of $80 \mathrm{~W} / \mathrm{m}^{2}$ produced an open-circuit voltage of $75 \mathrm{~V}$, a shortcircuit current of $7.2 \mathrm{~mA}$, a maximum power output of $0.301 \mathrm{~W}$, and a power conversion efficiency of $3.37 \%$. These results indicate that the DSC module can be applied as a solar window because it performed well both under direct light and low light intensities. The stability of the module was monitored for 279 days, and the results indicated that the short-circuit current significantly decreased, whereas for the open-circuit voltage, the decrease was less dramatic.

Keywords: dye-sensitized solar module; solar windows; sub-module; current-voltage; power conversion efficiency

\section{FULL TEXT}

(C) 2021 The Authors. Published by ESG (www.electrochemsci.org). This article is an open access article distributed under the terms and conditions of the Creative Commons Attribution license (http://creativecommons.org/licenses/by/4.0/). 